\title{
Å skape et begrep om jam i utforskningen av en deleuziansk metode-ontologi
}

\section{Med utgangspunkt $i$ arbeid med en lesesirkel}

\author{
Ola Harstad * \\ NTNU Norges teknisk-naturvitenskapelige universitet
}

\begin{abstract}
Sammendrag
Å forske med kunsten innebærer ikke bare valget av visse metoder for bruk i forskningsprosessen, men også om å ha til disposisjon spesifikke måter å tenke om metode. I denne artikkelen vil jeg synliggjøre en tenkemåte fundert i arbeidet med en skjønnlitterær lesesirkel for lærerstudenter, og min egen erfaring som improvisasjonsmusiker. Jazzens begrep om jam blir løftet frem som omdreiningspunkt for tenkemåten, som ellers har sitt teoretiske utspring i den franske filosofen Gilles Deleuze's forestilling om bliven. Denne vitale forestillingen innebærer at verden produseres kontinuerlig, noe forskeren også bidrar til. Koblingen mellom jam, litteratur og Deleuze synliggiør dessuten en måte å tenke om metode på som understreker at det å forske med kunsten ikke bare betyr å forske på kunsten, men at kunsten på ulike måter kan virke inn på selve forskningen og slik også bidra til å affirmere verden i sin bliven. I tillegg til å tilby en måte å tenke om metode for den som skal forske med kunsten, er hensikten med artikkelen å giøre forskeren bevisst sin egen tenkning om metode, noe som er viktig siden denne skaper mulighetsbetingelser for metodevalg og -bruk.
\end{abstract}

Nøkkelord: Gilles Deleuze; jazz; lererutdanning; skjønnlitteratur; improvisasjon

\begin{abstract}
Carrying out research with the arts does not only involve a particular choice of methods, but also the specific ways of thinking about these methods. In this article, I present a way of thinking based on the work of a reading circle for student teachers, and, my own experience as a jazz improvisation musician. The jazz concept of jam is central to this way of thinking, which above all draws its theoretical foundation from the French philosopher Gilles Deleuze's notion of becoming. Crucially, the notion postulates that the world is in a continuous process of becoming, a process in which the researcher is a contributor. The connection between jam, literature and Deleuze also reveals a way of thinking about method which emphasises that research with art does not only mean carrying out research on art, but instead that art can influence the research process itself and as such affirm the world in its becoming. In addition to offer a way of thinking about choice of methods in arts-based research, the
\end{abstract}

^Correspondence: Ola Harstad, Institutt for lærerutdanning, NTNU, 7491 Trondheim. Epost: ola.harstad@ntnu.no

(C) 2017 O. Harstad. This is an Open Access article distributed under the terms of the Creative Commons Attribution 4.0 International License (http://creativecommons.org/licenses/by/4.0/), allowing third parties to copy and redistribute the material in any medium or format and to remix, transform, and build upon the material for any purpose, even commercially, provided the original work is properly cited and states its license.

Citation: O. Harstad. "A skape et begrep om jam $i$ utforskningen av en deleuziansk metode-ontologi - med utgangspunkt $i$ arbeid med en lesesirkel". Fournal for Research in Arts and Sports Education, Special Issue: "A forske med kunsten" 
purpose of the article is to make the researcher conscious of his thinking about method. This is important since the way we think about method creates conditions for the choice and use of methods.

Keywords: Gilles Deleuze; jazz; teacher education; literature; improvisation

Received: May, 2017; Accepted: October, 2017; Published: December, 2017

\section{Å tenke om metode}

Hva er metode? Dette er et spørsmål som forskeren må stille seg fra tid til annen. Jeg stiller det for å rette oppmerksomheten mot noen av de grunnleggende forestillingene som ligger til grunn for bruken av ulike metoder i empirisk forskning. Dette er forestillinger som inngår i det som gjerne omtales som metodologi, som blant annet inkluderer epistemologi og ontologi (Koro-Ljungberg, 2016, s. 79). I denne artikkelen fokuseres det på den ontologiske dimensjonen ved metodologien, som jeg velger å kalle for metode-ontologi. "Ontologi» ${ }^{1}$ betegnes som læren om væren (Kvarv, 2010, s. 12), og min erfaring tilsier at det ikke er helt enkelt å innta et slikt metaperspektiv når man selv er i en forskningsprosess; særlig hensiktsmessig trenger det heller ikke å være. Forestillinger om væren er like fullt til stede, om enn implisitt, og i slike tilfeller kan forskerens metodevalg og -språk forstås som konsekvenser av disse (Gubrium og Holstein, 1997).

Forskeren gjør klokt i å reflektere over sine grunnleggende forestillinger om verdens beskaffenhet, all den tid disse genererer mulighetsbetingelser for metodebruk. I denne artikkelen stopper jeg derfor opp for å eksplisittere en type metode-ontologi gjennom å tilby ett mulig svar på spørsmålet om hva metode er. Svaret vil frembringes gjennom en utforskning av det metode-ontologiske potensialet i den franske filosofen Gilles Deleuzes forestilling om bliven ${ }^{2}$. Denne forestillingen innebærer at verden som vi forsker i og på, hele tiden blir til, noe som kan få omfattende konsekvenser for forskerens tenkning om - og bruk av - metode.

Det innledende spørsmålets ontologiske dimensjon - som synliggjøres gjennom bruken av «er» - påpeker at vi har å gjøre med et spørsmål om metodens væren. Samtidig som dette fordrer et relativt teoretisk svar, forutsetter Deleuze og Guattari (1991/1994, s. 21) at begrepsutvikling kun kan skje med utgangspunkt i en eller annen form for empirisk erfaring. I denne artikkelen skjer dette med utgangspunkt $i$ to ulike erfaringsområder, som begge har det til felles at de bringer kunsten inn i det metode-ontologiske resonnementet: For det første vil jazzens begrep om jam bli brukt som omdreiningspunkt for utforskningen av en deleuziansk metode-ontologi. Som musiker og slagverker har jeg en del erfaring med jam, som sier meg at dette kan være et fruktbart og hensiktsmessig (be)grep for å artikulere det performative, vitale og prosessuelle ved Deleuzes blivensforestilling. For det andre har utforskningen sitt utspring i arbeidet med en skjønnlitterær lesesirkel for grunnskolelærerstudenter,

\footnotetext{
${ }^{1}$ Av gresk «ontos»: «værende», dvs. det som er.

${ }^{2}$ «Bliven» er min oversettelse av det engelske «becoming» (fransk: «devenir»).
} 
som for øvrig inngår $\mathrm{i}$ et pågående avhandlingsarbeid om litteraturlæreren ${ }^{3}$. For å binde disse ulike elementene sammen til en teoretisk-empirisk helhet, arbeider jeg med utgangspunkt i følgende forskningsspørsmål: Hvordan er det mulig å skape tidrommet jam som omdreiningspunkt for en deleuziansk metode-ontologi, med utgangspunkt $i$ arbeid med en lesesirkel?

De to ovennevnte erfaringsområdene - jazzens jam og lærerstudentenes lesesirkel utgjør til sammen posisjonen forskningsspørsmålet undersøkes fra. Dette er en viktig påpekning, ettersom Deleuze kan forstås og anvendes på ulike måter (Olsson, 2014, s. 37). I denne artikkelen skjer dette altså i krysningen mellom litteraturdidaktikken og jazzen, hvor målet er å skape en jamtenkning om metode som vokser frem parallelt med et litteraturdidaktisk forsknings- og undervisningsarbeid.

Som forskningsspørsmålet synliggiør, vil jeg vise hvordan et begrep (jam) som uttrykk for en metode-ontologisk forestilling kan bli til, noe som på sett og vis operasjonaliserer Deleuzes forestilling om en verden i kontinuerlig bliven. Når han bruker dette begrepet (Deleuze og Guattari, 1991/1994, 1987/2013), erstatter det samtidig væren: Verden - og metode - er altså ikke, men blir. Dette får også konsekvenser for spørsmålet om hva metode $e r$, som ikke lenger kan betraktes som et «værensspørsmål», men et "blivensspørsmål». Dette påpeker for øvrig det problematiske i å bruke "ontologi» i et deleuziansk perspektiv, både fordi det ikke er snakk om en lære om det værende (men blivende) og fordi Deleuze ikke nødvendigvis skiller mellom ontologi og epistemologi ${ }^{4}$. Jeg kunne ha formulert spørsmålet «Hva er metode?», som riktignok påpeker at metode ikke er noe fast, men som likevel ikke helt griper det kontinuerlig blivende. Ved å ta konsekvensen fullt ut av å tenke metode-ontologi med Deleuze, kan derfor spørsmålet mer hensiktsmessig omskapes til: «Hvordan blir metode?» Denne måten å la blivensforestillingen også få språklige konsekvenser, er å finne i What is Philosophy? (Deleuze og Guattari, 1991/1994). Her distanserer Deleuze og medforfatter Felix Guattari seg fra en filosofi som søker å løse allerede gitte problem, og mener at det viktige er å skape begreper, avtegne og diagnostisere problemer, og slik tenke og ytre seg om verden på nye måter. I stedet for å finne, besvare eller løse, blir konsekvensen av å tenke med forestillingen om en verden i bliven heller å utforske, åpne opp og skape.

Som «byggesteiner» til jambegrepet vil jeg bruke to begreper som Deleuze (1991/1994, 1987/2013, 1977/2015) anvender for å operasjonalisere blivensforestillingen:

\footnotetext{
${ }^{3}$ Pågående fra 2014-2018 med arbeidstittel: Mot en mindre litteraturlerer. En fremskriving av problemet om litteraturlcererens bliven.

${ }^{4}$ Karen Barad (2007) operasjonaliserer denne forståelsen med begrepet "onto-epistemologi», som også kunne være aktuelt for meg. Denne termen inkluderer riktignok den epistemologiske dimensjonen i den ontologiske, men erstatter samtidig ikke «onto» med noe som synliggiør en lære om det blivende. En mulighet for å oppnå sistnevnte er å lage et nytt ord fundert i et gresk ord for «becoming» ("thelktikós») eller bruke gjennomstrekning ("metode- entelegi »). Dette er imidlertid omstendelige og ikke nødvendige løsninger i denne sammenhengen, hvor jeg bruker «metode-ontologi» for å rette oppmerksomheten mot grunnleggende forestillinger om verdens beskaffenhet i en forskningsmetodologisk kontekst.
} 
Begivenhet og sammensetning 5 . Begivenhet er et begrep om nået hvor noe nytt produseres, og fremhever dermed blivens temporalitet. Fra dagligtalen kjenner vi en begivenhet som en stor hendelse, men i denne sammenhengen kan det like gjerne være i det en liten og nesten umerkelig hendelse inntreffer: En idé, et lesesirkelmøte, en assosiasjon i møte med en roman - for eksempel. Sammensetningen vektlegger samspillet av mening og materie som virker sammen $\mathrm{i}$ begivenheten: Meningen som skapes i møtet med en bok, bokens papir og perm, rommet vi befinner oss i, etc. Slik sett fremhever sammensetningen blivens spatialitet. Ettersom begivenhet og sammensetning dermed fremhever blivens tid og rom, lar jeg disse virke sammen i skapningen av jambegrepet som et "tidrom». Denne termen er hentet fra Theodore Schatzki (2013, s. 23) som påpeker at menneskelig aktivitet ikke skjer $i$ tid og rom, men at tidrom er noe som åpnes og skapes av aktiviteten selv ${ }^{6}$. Hensikten er altså å skape et metode-ontologisk jambegrep som åpner opp et bestemt tidrom for tenkning om metode, og der igjennom bidra til en form for metode-ontologisk bevisstgjøring for den empiriske forskeren, som inviteres til å tenke med - og imot der det måtte passe.

\section{Rigid metodikk og vitalistisk etikk}

Behovet for en metode-ontologisk bevisstgjøring starter allerede med metodebegrepet. Hans-Georg Gadamer (2003, s. 21) påpeker at ordet (av gresk: «methodos») gir betydningen "vei å følge», og hevder videre at vitenskapens fremgangsmåte nettopp kjennetegnes av å gå den samme vei som tidligere er gått. I Thinking with Theory in Qualitative Research (2012, s. 7) argumenterer Alecia Jackson og Lisa Mazzei for at mange av metodeveiene som finnes og følges, er rigide, reduserende og simplistiske; at forståelse av en kompleks verden ikke kan skje gjennom "mekanisk koding», «reduksjon av data til temaer» eller "fremskriving av transparente narrativ». Selv om kritikken rammer bredt, synliggjør den en metode-ontologisk utfordring, kanskje spesielt for empirisk lærerutdanningsforskning: Mange metodeveier følges og reproduseres, kanskje ikke fordi de egner seg spesielt godt til anvendelse på en kompleks verden, men simpelthen fordi de allerede foreligger.

Jackson og Mazzei (2012) foreslår å tenke med teori som i stor grad krever at forskeren selv skaper veien med utgangspunkt i sitt prosjekt, og en av teoretikerne som blir trukket fram som egnet til dette, er nettopp Gilles Deleuze. Grunnen til dette kan være hans fleksible perspektiver som i stor grad tilbyr et metode-ontologisk potensial, som det så er opp til den enkelte forsker å realisere som metode. En deleuziansk metode-ontologi kan imidlertid være problematisk, ettersom Deleuze har vært

\footnotetext{
5«Begivenhet» og «sammensetning» er mine oversettelser av de engelske «event» og «assemblage» (fransk: «événement» og dispositif»/《agencement»).

${ }^{6} \mathrm{Et}$ annet mulig begrep om tidrom kunne være Mikhail Bakhtins (1986/2006) «kronotop». Dette er imidlertid ikke valgt til denne sammenhengen fordi det primært er laget for å synliggiøre tidrom i romaner.
} 
ansett som en produsent av «høyteori». Det vil si som et sett av idéer som fungerer på et abstrakt plan, men som har lite med empirisk forskning å gjøre (Coleman og Ringrose, 2013). Selv om denne innvendingen ikke er urimelig, er det likevel flere som også har blitt oppmerksomme på Deleuzes filosofi som en av få som kan anvendes i direkte relasjon til hverdagslig praksis (Olsson, 2014 s. 37). En av disse er Camilla Andersen (2012), som påpeker at Deleuzes blivensforestilling også innebærer en «vitalistisk etikk», ettersom den ikke bare slår fast at verden er i kontinuerlig bliven, men også handler om å affirmere denne. Dette poenget understreker at det ikke er mulig å snakke om en «ren» deleuziansk ontologi - løsrevet fra epistemologi eller metode men at det ligger innskrevet i den å si «ja» til det forskningen bidrar til å skape. På den måten er blivensforestillingen rettet mot å utforske nye veier fremfor å følge de allerede foreliggende.

Dette peker mot forskningens performative aspekt, hvor forskeren anerkjenner sin deltakelse som skapende aktør i det som studeres og utfallet av deltakelsen ikke er mulig å predeterminere. Det performative er viet relativt mye oppmerksomhet innenfor feltet som gjerne omtales som Arts-Based Research (ABR) (Leavy, 2015), hvor det performative også gjerne kobles sammen med ulike former for kunst. I og med at jeg gjør slike koblinger mot jazz og skjønnlitteratur, kan denne artikkelen ses som et bidrag til ABR-feltet. Å koble kunsten med forskningen er også hensiktsmessig med hensyn til blivensforestillingen, som nettopp innebærer å anerkjenne kunsten som en sentral bidragsyter til en verden i kontinuerlig bliven (Colebrook, 2002). Dette er det flere årsaker til, men kunstens evne til å skape nye koblinger mellom gamle elementer kan trekkes frem som spesielt viktig. Slik sett kan performativ forskning som på ulike vis befatter seg med kunst, være et spesielt egnet sted for å tenke med Deleuzes blivensforestilling.

\section{Ulike erfaringsområder og kolliderende forestillinger}

Mine første tanker om å bringe kunsten inn i min forskning kom da jeg for om lag to år siden bidro til å starte en lesesirkel for grunnskolelærerstudenter. Sirkelen pågikk i cirka ett år, var et frivillig opplegg for engasjerte studenter og var ikke opprinnelig tenkt som en del av ovennevnte avhandlingsarbeid. Vi var åtte personer og møttes omtrent en gang i måneden for å diskutere romaner. Ettersom sirkelen oppstod litt på siden av de ordinære emnene i lærerutdanningen, stod vi fritt til å arbeide med litteraturen på den måten vi selv ønsket. Resultatet ble en type litteraturarbeidspraksis som i stor grad blir til underveis og med utgangspunkt i den enkelte roman. Inspirasjonen kom fra Aslaug Nyrnes' (2002, s. 13) begrep om "mindre didaktikk ${ }^{7}$ », en didaktikk som alltid blir til med utgangspunkt i det singulære (som én tekst) og eksempelvis ikke i generell litteraturdidaktisk teori eller styringsdokumenter. Selv om sirkelen ikke brøt med etablerte oppfatninger om litterære samtaler (Aase, 2005), var

${ }^{7}$ Som igjen er inspirert av Deleuze og Guattari (1975/1986). 
det likevel noe alternativt over den i en lærerutdanningskontekst, hvor litteraturens nytteverdi med hensyn til fremtidig bruk i skolen er det primære.

At vi arbeidet med litteraturen på denne måten - hvor kunsten selv får legge premiss for undervisning om den - gjorde at jeg som musiker tenkte på lesesirkelen som en jam hvor vi improviserte over den leste teksten. "Jam» eller «jam-session» blir gjerne definert som en uformell sammenkomst for jazzmusikere som foregår for deres egen fornøyelses skyld (Store Norske Leksikon, 2016). Ifølge egen erfaring mener jeg i tillegg jammen handler om å utvikle seg, prøve ut gammelt og nytt, eksperimentere og forstå hvordan man spiller sammen. Dette tenkte jeg i hvert fall om lesesirkeljammen etter at den hadde blitt en del av avhandlingsarbeidet: Som et sted for å eksperimentere med litteraturlærerbliven i møte med litteratur.

Denne måten å koble jam til en læringssituasjon er allerede gjort av Anne Pässilä, Allan Owens og Maiju Pulkki (2016), som nettopp utvikler det fruktbare begrepet «Learning jam». Når jeg ikke skaper et jambegrep for undervisnings- eller forskningsmetode, men til den metode-ontologiske tenkningen som vokser ut av lesesirkelarbeidet, er det fordi sistnevnte virket tilbake på mine grunnleggende forestillinger om metode: Jam har blitt en måte å tenke om metode og verden på, som nettopp muliggiør koblingen mellom jambegrepet, Deleuze og lesesirkelen. Dette understreker hvordan denne typen metode-ontologi ikke blir til gjennom abstrakt teoretisering, men i selve forsknings- og undervisningsprosessen. At sistnevnte fikk omfattende konsekvenser, ble tydelig da jeg fikk idéen om å innlemme sirkelen i avhandlingsarbeidet, og selv møtte idéen med innvendinger av typen: Dette var da ikke planlagt fra starten av? Du er jo med i lesesirkelen selv, har du hørt om sunn distanse til det du undersøker, og hva i lesesirkelen skal du egentlig undersøke? Hvordan skal dette kunne etterprøves? Det oppstod altså en konfrontasjon mellom to ulike forestillinger om hva metode er: Den "gamle» som gjorde meg opptatt av å følge de forskningsmetodiske veier som allerede foreligger, og den "nye» som fikk meg til å lete etter muligheter for å skape nye koblinger og på den måten bidra til å affirmere verden i sin bliven.

At det var en annen metode-ontologisk tenkning jeg var i ferd med å etablere, ble spesielt tydelig for meg idet jeg som forsker åpnet for å koble metodetenkningen til mitt musikalske erfaringsområde og jambegrepet. Slike koblinger finnes det allerede flere av, blant annet innenfor det ovennevnte ABR-feltet. Terry Jenoure (2002), Norma Daykin (2004) og Liora Bresler (2005) er eksempler på forskere som har utviklet metaforiske begrepsapparat for forskningsmetode med termer fra musikkens verden. Felles for disse eksemplene er deres bidrag til å giøre forskere mer sensitive og oppmerksomme overfor en flyktig sosial verden, blant annet gjennom å artikulere aspekter ved den sosiale verdenen som ellers ville vært utilgjengelige (Leavy, 2015, s. 133). Jackson og Mazzeis kritikk imøtekommes på sett og vis av slike bidrag, samtidig som det er en mulighet for at også de vil bli rammet av den, ettersom slike begrep kun vil være mulig å anvende hvis de passer til det enkelte forskningsprosjekt. Av den grunn mener jeg det er behov innenfor ABR-feltet for å opprette koblinger, ikke bare mellom musikk og metode, men også mellom musikk og metode-ontologi. 


\section{O. Harstad}

\section{Jazz og metode-ontologi}

Innenfor den metode-ontologien som jeg kaller jam, befinner forskeren seg $\mathrm{i}$ et prosessuelt mellom(tid)rom. Et nå, som nettopp er mulig å se som parallelt til jazzens og jammens verden. I Thinking in fazz. The Infinite Art of Improvisation (1994, s. 51) viser Paul Berliner hvordan jammen inngår som en viktig bestanddel i jazzens uformelle «utdanningssystem». Dette er et system som vektlegger læring i kontinuerlig prosess, og hvor den som lærer seg, ansvarliggiøres med hensyn til hvor man skal gå videre i prosessen for å skape seg selv som jazzmusiker. Selve jamsituasjonen forblir også åpen og uavsluttet fordi man på forhånd ikke vet hvor veien går videre, eller hvor det hele ender. En viktig bestanddel for å etablere jammen i dette mellomrommet er improvisasjon, som ifølge min gamle metode-ontologiske forestilling var et «nødvendig onde» man tyr til når ting ikke går etter planen. En slik forståelse bygger på det Geir Karlsen (2006) omtaler som en "teknisk rasjonalitet", som fordrer en «forutsigelsesteknologi» som sikrer at man følger en allerede kjent vei fra start til mål. For Deleuze og Guattari (1987/2013, s. 277) produserer imidlertid ikke bliven noe annet enn seg selv, noe som innebærer at resultatet ikke kan sammenliknes med noe (som fortsatt ikke finnes). Det skapes altså noe nytt. Og selv om dette nye ikke kan predetermineres, følger det likevel en retningsbestemt «lov»: Vekk fra det samme.

Nå kan det virke som jeg postulerer en «fri» metode-ontologi som ikke forholder seg til det «rigide» som finnes fra før, hvor metoden som realiseres handler om «å være i nået”, uten å ta hensyn til det som kom før og det som skal komme etter. Autonomiestetiske diskurser omkring jam og improvisasjon, som nettopp har en tendens til å dyrke en romantisk forestilling om den frie utøver som skaper noe helt nytt og originalt, uavhengig av det gamle, er temmelig utbredte i jammens og improvisasjonens verden (Peters, 2009; Steinsholt og Ness, 2016). Min hensikt er derfor ikke bare å ta konsekvensen av Jackson og Mazzeis kritikk om rigid og reduserende metodebruk, men også å supplere, nyansere og utfordre en del av disse romantiske forestillingene om jam og improvisasjon. For når jeg selv deltar i en jam, improviserer og bidrar med andre musikere i å skape noe nytt, er ikke min erfaring at dette giøres i et vakuum. Tvert imot tror jeg alle improvisasjonsvalgene vi tar, kommer fra tradisjoner, erfaring og forventninger som giør at vi har en viss følelse for hva som er rett eller galt å giøre i neste øyeblikk. Samtidig tar vi ikke sikre avgjørelser, ettersom vi er stilt overfor det som ennå ikke er (Karlsen, 2006). På denne måten handler jammen om å være i et mellomrom eller «nå» som kjennetegnes av å være på grensen mellom det styrte og frie, sikre og usikre eller det å vite og ikke vite.

Jammens metode-ontologiske tidrom som sammensetning og begivenhet

I det videre skal jeg se mer inngående på jammens tidrom gjennom Deleuzes begreper om begivenhet og sammensetning. Hensikten er å forstå mer spesifikt hvordan bliven, det vil si produksjonen av noe nytt, skjer rent ontologisk og hvordan dette blir virkeligheten slik den fremstår. Og som i jazzens jam, produseres det nye hos Deleuze i samspill med det som allerede foreligger. 
$\AA ̊$ etablere forestillingen om en verden i bliven innebærer å akseptere at vi som forskere ikke bare representerer verden, men også bidrar til å produsere den. Ifølge Deleuze og Guattari (1987/2013) skjer virkelighetsproduksjon som en temporal og spatial ordning av det som i utgangspunktet er et kaos av båndfrie diskursive og materielle strømninger. Slik sett er forskerens oppgave å ordne kaos av mening og materie. Kort fortalt skjer ordningen ifølge Deleuze og Guattari (ibid.) gjennom stratifisering (lagdannelse), og virkeligheten holdes dermed relativt stabil av lag som har blitt til over tid. Et eksempel fra jazzens verden kan være sjangerkategorien «jazz» som er en ordning som har pågått i litt over hundre år, som involverer både mening og materie. Resultatet blir «jazz» som kommer i ulike tapninger, nettopp fordi det finnes litt ulike lag som til sammen utgiør helheten. Stabilitet og endring som følge av ordning giennom lagdannelse er også noe vi kjenner igjen fra forskningens verden, eksempelvis med hensyn til spørsmålet «Hva er metode?», som besvares (og stilles) på ulike måter til ulike tider (Macnaghten og Myers, 2004). Det interessante med lagdannelsen er at den ikke skjer som dannelsen av ett og ett lag, men alltid minst to. "Jazz» eller «metode» er derfor en sammensetning, som ifølge Deleuze og Parnet (1977/2015, s. 75$)$ er å forstå som et samspill av ulike linjetyper som kan illustreres slik:

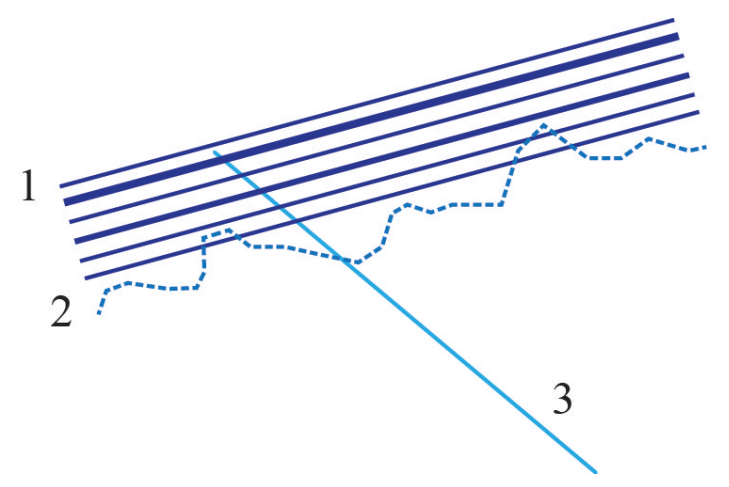

Figur 1. Illustrasjon av sammensetningens ulike linjetyper. (Harstad, 2017)

Den første linjetypen (1) består av den molare segmenteringen. Dette er linjer som har blitt stratifisert over lang tid, og som dermed oppfattes som temmelig stabile. I forbindelse med ovennevnte ph.d.-prosjekt og lesesirkel kan disse linjene knyttes til lærerutdanningens styringsdokument med sin målstyring, etablert litteraturundervisningspraksis og litteraturdidaktisk teori. Med hensyn til metodespørsmålet jeg stiller, kan de molare segmenteringslinjene sies å være fundamentet for det jeg har omtalt som min "gamle» og reproduserende metodeforestilling. Når Jackson og Mazzei (2012) kritiserer rigid og reduserende metodebruk, kan det også sies å være de molare linjene som omtales. Ifølge Deleuze og Parnet (1977/2015, s. 168) er denne linjetypen knyttet til et metafysisk organisasjonsplan, som råder over formene og subjektene i virkelighetsproduksjonen, noe som innebærer at både en reproduserende metodeeller litteraturlærerbliven kan forstås ut fra den molare segmenteringens stratifisering. 
Samtidig foregår det bliven som ikke nødvendigvis sammenfaller med den harde, synlige og "offisielle» linjetypen (1). Dette leder meg over til den andre linjetypen (2), som omtales som molekyler segmentering (Deleuze og Parnet, 1977/2015, s. 162). Denne linjetypen er viktig i denne sammenhengen fordi den blir til under den molare, men i motsetning til sistnevnte er den molekylære mer smidig og ikke nødvendigvis sammenfallende med nr. 1. Som lag er det molekylære mer porøst enn det molare, og innehar derfor muligheter for en annen type bliven. Dette er fordi den molekylære segmenteringen ikke er knyttet til organisasjonsplanet, men et immanensplan som inneholder det ovennevnte kaoset som hele tiden ordnes. Hvis jeg igjen knytter an til jazzens verden, er det mulig å forenklet se for seg jazzen som fremtrer på konserter, plater og jazzkonservatorier som den molare segmenteringen, mens jammen som foregår på lugubre kneiper er den molekylære. Noe liknende er det også mulig å betrakte lesesirkeljammen. For selv om vi oppretter den tett opp til lærerutdanningens molare segmentering (vi befinner oss eksempelvis på campus, bruker møterom, jeg er faglærer, informantene er lærerstudenter), er vi likevel i et mer smidig rom (eks. uten emnebeskrivelser, eksamen, arbeidskrav, pensum) hvor vi gir oss selv muligheten til å diskutere litteratur, for eksempel uten at diskusjonene nødvendigvis skal ha en retning mot en fremtidig bruk i et klasserom. Den molekylære segmenteringen er slik sett jammens linje, ettersom den kan ses på som noe mer uformell og uoffisiell enn den molare.

Den tredje linjetypen (3) i sammensetningen er den Deleuze og Parnet (Deleuze og Parnet, 1977/2015, s. 162) omtaler som "fluktlinjen». Denne er uforutsigelig, både med hensyn til hvor og når den oppstår og hvor og når den ender. Hvis det er en rekkefølge på bliven som virkelighetsproduksjon i en sammensetning (som min rekkefølge indikerer), oppstår fluktlinjen etter 1 og 2. Det er fordi den utnytter revner og sprekker i de andre lagene i forsøket på å destabilisere sammensetningen. Det er først når fluktlinjen lykkes i å løsrive seg fra de andre lagene, at det faktisk blir en fluktlinje, og det er da - $i$ det fluktlinjen tegnes - at man oppfatter at det skapes noe nytt, nettopp som en flukt fra det gamle. Betyr det at jam som metode-ontologisk forestilling innebærer å betrakte forskning som noe som må etablere seg som molekylær linje, eller gå inn for å skape fluktlinjer? Ettersom man på forhånd ikke vet hva som vil fungere som fluktlinje eller formen på det som kan blokkere den og tilbakeføre den til den molare segmenteringen, er det vanskelig å skape fluktlinjer intensjonelt (Deleuze og Parnet, 1977/2015). Forskning fundert i et ønske om å affirmere verden i sin bliven vil altså være som en ordinær musikerjam: Ingen sikker aktivitet for den som ønsker å skape noe nytt. Det beste man kan gjøre, er derfor å lete etter og skape potensialet for noe nytt ved å la hele sammensetningen virke, uten å vite med sikkerhet når det nye vil kunne skje.

Det som imidlertid inntreffer, hvis og når noe nytt skjer, sier Deleuze, er en begivenhet. Det er temporaliteten når hele sammensetningen - med de ulike linjetypene - virker sammen i skapningen av noe nytt. Det betyr at når forskere ofte er representanter for den molare segmenteringen, settes det også i gang en hel del utenfor deres kontroll, noe det også skal gjøre, ettersom det er i det fluktlinjen unnslipper 
at potensialet for det nye er til stede. Denne helhetsforståelsen er viktig, fordi det også distanserer det metode-ontologiske jambegrepet fra den romantiske forestillingen om at det nye skapes i et slags fritt rom eller vakuum. Tvert imot viser sammensetningen at verken den molekylære linjetypen eller fluktlinjen eksisterer uten den molare. Følgelig er ikke jamtidrommets «nå» en begivenhet som kun skaper én av linjetypene, ettersom «nå» ikke er noe som helst uten fortid og fremtid: Som begivenhet inneholder «nå» til og med fortid og fremtid (Deleuze og Parnet, 1977/2015; Deleuze, 1968/2014). Jammens tidrom må dermed forstås på to måter: A) Som molekylær segmentering i sammensetningens mellomrom (mellom linje 1 og 3), hvor den fortsatt er helt avhengig av den molare segmenteringen for å oppstå som et slags uoffisielt alternativ, og B) En begivenhet som inneholder hele samspillet i sammensetningen i skapningen av noe nytt. Dette betyr at det nye alltid allerede er innskrevet som et potensial i det gamle, og at disse virker i sammensetningen/begivenheten. Slik sett er Deleuzes blivensforestilling parallell til Gary Peters' (2009) sykliske oppfatning om jam og improvisasjon som re-novasjon, hvor det samme gamle returnerer til seg selv som noe nytt og forskjellig: en prosess som kan sies å uttrykke det metafysiske samspillet mellom kaos og ordning.

\section{Litteraturen - et laboratorium for virkelighetsproduksjon}

Ovenfor har jeg synliggjort blivensforestillingen gjennom å vise hvordan hele sammensetningen virker sammen i produksjonen av noe nytt som giør at fortid, fremtid og nåtid blandes i én begivenhet. Da virker det kanskje som om alt er like viktig i produksjonen av det nye: hver minste kommentar, forskerens klær, ulike metodetradisjoner, været utenfor vinduet, informantenes sinnsstemning etc. Alt virker i sammensetningen. Og jeg tror nok også at alt, samme hvor lite det er, har sin plass og bør anerkjennes. Samtidig er noe viktigere enn annet.

Som jeg allerede har nevnt, har kunsten en vital funksjon i å åpne opp et metode-ontologisk tidrom for å affirmere verden i sin bliven, en funksjon Martin Heidegger (1935/2000, s. 86) oppsummerer slik: «Ut fra kunstens diktende vesen skjer det at kunsten slår opp et åpent sted midt $\mathrm{i}$ det værende, hvor alt er annerledes enn ellers». Blant kunstformene trekker Deleuze (1975/1986) frem litteraturen som sin foretrukne, og mener denne i seg selv er en begivenhet som skaper nye koblinger mellom gamle elementer, og slik sett er den et laboratorium for virkelighetsproduksion. Dette innebærer at litteratur er noe som virker og får en effekt, eksempelvis fremfor at den er noe som skal tolkes. Dette er et poeng jeg løfter frem fordi det ikke bare er interessant for lesesirkelen i ph.d.-prosjektet, men også for metodetenkningen omkring sirkelen, ettersom det lar meg åpne for at litteraturens «annerledeshet» får virke inn $i$ avhandlingens resonnement på en annen måte enn at den kun representeres som en bestanddel i lesesirkelen. Dette vil jeg avslutningsvis eksemplifisere gjennom å ta utgangspunkt i en konkret hendelse fra lesesirkelen, for så å se hvordan boken vi leser og diskusjonen som føres, bidrar til å skape en kontekstforståelse til bruk i 


\section{O. Harstad}

avhandlingen. Denne bevegelsen er spesielt viktig for å vise hvordan jeg lar kunsten, dvs. effekten av litteraturen, virke inn i avhandlingsarbeidet, $o g$ at det som muliggiør en slik kobling, nettopp er den grunnleggende metode-ontologiske forestillingen om verden og metode jeg kaller jam.

Den første romanen vi tok for oss i lesesirkelen var Epp (1965/2002) av Axel Jensen. Dette er i seg selv et tekstvalg som per nå ikke er å finne i lærerutdanningens pensumlister, men som heller ikke ville være uaktuelt. Slik sett er det et valg fundert i sammensetningens molekylære segmentering, men som fort kan bli ført opp i den molare. Romanen omhandler et dystert fremtidssamfunn hvor en totalitær stat har sørget for at alle store problem er løst, automatisert eller gjort om til fjernsynsunderholdning. Den enkelte er redusert til en brikke i et maskineri hvor den ikke har noen annen rolle enn å reprodusere samfunnets definerte mål. Protagonisten, Epp, er en kald og ganske kynisk forbruker, som ikke evner å tenke forbi seg selv og sitt eget: et produkt av dette samfunnet. Han bor i en blokkleilighet hvor han bruker tiden på å føre rapport, noe som understreker overvåkingssamfunnet han selv bidrar til å opprettholde. Inn til hans og alles leiligheter er kikkhullene erstattet med "Judasøye» som det er mulig å se gjennom fra begge sider, noe som skaper en bestemt type «åpenhet» mellom "Inspektørene» og beboerne. Som dystopier flest, kan romanen være egnet til å få leseren til å tenke om seg selv og sitt samfunn, noe jeg også påpekte overfor lesesirkeldeltakerne. Ettersom jeg da fremholdt en relativt vanlig oppfatning om dystopier, kan påpekningen sies å være fundert i litteraturfaglighetssammensetningens molare segmentering. Lærerutdanningen er nok en litt annen sammensetning, hvor den molare segmenteringen i større grad omhandler fremtidig bruk av litteratur i et klasserom. På denne måten ble det opprettet en molekylær segmentering i lærerutdanningens sammensetning hvor vi forholdt oss til den molare segmenteringen ved å ta avstand fra den.

I sirkelen startet vi med en runde der alle fikk si noen innledende ord om sin egen lesning, og åpnet dermed for de ulike mulighetene romanen som begivenhet hadde skapt. Jeg vil trekke frem enkelte aspekt fra mitt feltnotat datert 18.11.15. Her kommer det blant annet frem at lesesirkelmedlemmet "Britt» så paralleller mellom romansamfunnets fiendestat og de ulike stater vi i vesten er fiender med, som skaper og opprettholder forestillingen mellom «oss» og «dem». «Johanne» påpekte videre vårt samfunns tendens til å stue bort eldre mennesker og behandle dem som byrder. Epp og de andre beboernes boforhold i blokken fikk henne til å assosiere til sin demente bestemor på sykehjemmet. «Stian» påpekte at Epp var illustrert av Hariton Pushwagner, noe som også ledet oss til bildet Getting up av Pushwagner som henger ved hovedinngangen på campus ved lærerutdanningen. Dette var, ifølge «Stian», morsomt fordi vi hver dag får påpekt at vi er flittige arbeidsmaur av dette bildet. Det var altså mulig å skape fluktlinjer fra lærerutdanningens molare segmentering, med utgangspunkt i de ulike lesernes erfaringer når vi lot teksten virke på dette viset, uten noen bestemt plan annet enn å snakke om teksten. Selv om slike assosiasjonsrunder sjeldent skaper det jeg anser for å være det mest givende litterært sett (nå er det litteraturfaglighetens molare 
segmentering som igjen prater), kan det være en relativt enkel måte å operasjonalisere jam som undervisnings- og forskningsmetode på: Uten predeterminert mål for seansen giør de ulike bidragsyterne sitt beste for å spille sammen og improvisere over den leste teksten med utgangspunkt i sin egen erfaring. I den forbindelse er det også relevant å nevne at lesningen og diskusjonen rundt $E p p$ førte til at vi ble enige om å lese flere dystopier, noe vi også gjorde. I ettertid ser jeg dermed at det er mulig å betrakte lesesirkelen som en dystopifokuserende lesesirkel, som har satt seg inn i flere sentrale tekster av denne typen, noe det ikke var mulig å vite på forhånd.

Hvis vi nå beveger oss fra en type «learning jam» til jam som tenkning om metode, fikk denne lesesirkeljammen også effekt for meg og min avhandling. Dette skjer på flere måter, hvor én er at jeg som medlem av lesesirkelen og forsker på den, også kan følge i lærerstudentenes spor og anlegge et dystopisk syn på det «samfunn» som er i fokus i avhandlingen, dvs. skole, lærerutdanning og litteraturdidaktikk. Epp, og lesesirkelens behandling av den, har nemlig virket ved å tilby en spesifikk kontekstforståelse for avhandlingens undersøkelse. Denne bevegelsen muliggiøres nettopp av den metode-ontologiske forestillingen om jam, ettersom sistnevnte åpner opp og skaper et tidrom for å affirmere verden i bliven som jeg bidrar til å produsere giennom min avhandling. I avhandlingen ser dermed deler av kontekstforståelsen slik ut:

Det er, som de andre lesesirkeldeltakerne hevder, mulig å gjenkjenne noen «dystopiske» trekk som kan bidra til å anlegge et spesifikt syn på den konteksten som føder dette prosjektet. Gunilla Dahlberg og Peter Moss (2014) hevder at vi lever $i$ en verden hvor vi trues av et "diktatur uten alternativ»; et neoliberalistisk regime hvis totaliserende fortelling om nødvendigheten av konkurranse, kalkulering og individuelle valg må utføres av det foreskrevne subjektet: homo economicus, som også ville kunne karakterisere Epp. Denne fortellingen kommer, ifølge forfatterne, til uttrykk $i$ en utdanningsdiskurs som er hengiven og lojal til produksjonen av generiske individer hvis funksjon er å bidra til markedsøkonomisk vekst. I forlengelsen av en slik påstand er det interessant å påpeke at OECD, som står bak undersøkelser som PISA og «lesing som grunnleggende ferdighet», arbeider for «(..) policies that will improve the economic and social well-being of people around the world" (OECD, 2015). «Lesing» får slik sett en spesifikk definisjon, hvor nytteverdien blir sentral. Denne må videre kunne måles, gjennom undersøkelser som PISA (Harstad, pågående ph.d.-avhandling).

Som utdraget viser, lar jeg EPp og lesesirkelens behandling av den, virke inn på min kontekstuelle forståelse gjennom «å lese» konteksten gjennom Epp. På denne måten bidrar kunsten til å styre forskerblikket på et bestemt vis, og gjør at jeg finner og setter sammen kilder som allerede eksisterer på en ny måte.

\section{Å jamme med teori}

I denne artikkelen har forskningsspørsmålet Hvordan er det mulig å skape tidrommet jam som omdreiningspunkt for en deleuziansk metode-ontologi, med utgangspunkt $i$ arbeid med en lesesirkel? blitt til samtidig som det framvoksende spørsmålet har veiledet meg i prosessen som har blitt til. Som et slags resultat har jeg forsøkt å vise frem en måte 
å tenke om verden og metode på, gjennom å skape et metode-ontologisk begrep om jam som tilbyr ett svar på hva metode er. Ettersom jeg viser hvordan jambegrepet skapes, er artikkelen å betrakte som en operasjonalisering av det den selv forsøker å frembringe. I utforskningen har jeg blitt klar over at det ikke er så mye hva Deleuze tenker, når han skriver frem sin blivensforestilling, som hvordan han tenker. Og det er denne tenkemåten som hjelper til med å skape nye koblinger mellom gamle elementer (eksempelvis mellom jazzens jam, metodologi og en lesesirkel, eller Epp og konteksten for en avhandling om litteraturlæreren), jeg ser som det fruktbare med å etablere et metode-ontologisk begrep om jam.

Jeg har gitt ett innblikk i utviklingen av jam som metode-ontologisk begrep og hvordan den har sitt empiriske utgangspunkt. Samtidig har jeg påpekt at forskerens metode-ontologiske forestillinger også virker tilbake på metodebruk. Ettersom Deleuze kan leses og forstås på en rekke ulike måter, er det både vanskelig og problematisk å skulle generalisere en fremgangsmåte for en forskningsmetode fundert $\mathrm{i}$ jam som metode-ontologi. Jeg vil derfor understreke behovet for at forskeren selv går i dialog med Deleuze. Da er det også viktig å være oppmerksom på at det er en fare for at «å tenke med teori» også blir en rigid øvelse, hvor man ikke tillater seg å giøre noe hvis ikke dette synes "godkjent» av Deleuze. Derfor mener jeg det er avgiørende å betrakte blivensforestillingen som et metode-ontologisk potensial som kan realiseres metodisk på ulike måter slik at man settes i stand til «å jamme med teorien».

Helt avslutningsvis vil jeg problematisere den grunnleggende forestillingen jeg har bidratt til å eksplisittere. Som jeg har vært inne på, innebærer eksempelvis jam som metode-ontologisk forestilling at forskning er performativ, ettersom forskeren bidrar til å produsere virkeligheten, både diskursivt og materielt. I tillegg innebærer det performative i denne sammenhengen aktivt å gå inn for å affirmere verden i sin bliven der hvor mulighetene dukker opp, noe som for øvrig viser hvordan en deleuziansk ontologi aldri er løsrevet fra epistemologi, etikk eller metode. Denne omfattende vitalismen kan imidlertid være problematisk, ettersom man metode-ontologisk sett kan ende opp med å si «ja» til noe man faglig eller moralsk sett helst sier «nei» til. I den forbindelse er det viktig å påpeke det potensielt problematiske med Deleuzes «vitalistiske etikk», som kanskje ikke bør følges uansett. I en musikerjam medfølger et ansvar overfor musikken og medmusikanter, et ansvar jeg mener forskeren også bør etablere i den metode-ontologiske utgaven av jammen. Det kan også innebære å si «nei» i rette øyeblikk. For mitt vedkommende kan dette bli aktualisert i lesesirkelen, hvor jeg som litteraturlærerutdanner har muligheten til å støtte og anerkjenne en eller annen assosiasjon en av de andre leserne får i møte med en bok (fordi dette vil være noe nytt), eller problematisere og til og med diskvalifisere assosiasjonen fordi den simpelthen er lite faglig relevant i vår sammenheng.

Et annet potensielt problematisk aspekt ved jam som metode-ontologisk forestilling er å tenke i sammensetninger og begivenheter. For selv om disse uten tvil kan være egnet for å "fange» det komplekse samspillet som virkeligheten utgiøres av, kan de også fange forskeren i forestillingen om at alt henger sammen med alt, slik at hun/ 


\section{A skape et begrep om jam i utforskningen av en deleuziansk metode-ontologi}

han blir ute av stand til å fokusere. Én mulighet er å forske med kunsten og fokusere på effekten av denne koblingen, slik jeg har forsøkt å vise med eksempelet fra lesesirkelen. En annen mulighet er simpelthen å fokusere på det som i det enkelte forskningsprosjekt synes å være mindre viktig, all den tid fluktlinjer kan være bittesmå og gjerne umerkelige.

Jam som begrep for en deleuziansk metode-ontologi er etter min mening noe intuitivt, og jeg er usikker på om skapningen av begrepet frambringer noe helt nytt. Kanskje kan begrepet likevel forstås som en molekylær segmentering som bidrar til å gjøre forskningsforståelse noe mer porøs, som affirmerer kunstens potensial til å bidra til forskningsmetodologisk utvikling og som bidrar til å si noe gammelt på en litt ny måte.

\section{Forfatteromtale}

Ola Harstad leverte master i Norskdidaktikk ved Høgskolen i Sør-Trøndelag 2012, hvor han undersøkte bakgrunnen for ungdomsskolelæreres valg av skjønnlitteratur. Harstad arbeidet ved samme institusjon som lektor fra 2012-2014, både ved grunn- og masterutdanningen. Fra 2014-2018 er han stipendiat ved Institutt for pedagogikk og livslang læring (NTNU). Avhandlingsarbeidet er orientert mot litteraturundervisning i lærerutdanningen, og oppstår i krysningspunktet mellom pedagogisk filosofi og litteraturdidaktikk. Harstads forsknings- og undervisningsinteresser er knyttet til litteraturarbeid, litteratursosiologi, språk-, kultur- og kunstfilosofi. For øvrig spiller han slagverk og bedriver oppussing av gamle økser.

\section{Referanser}

Aase, L. (2005). Litterære samtalar. I B. Nicolaysen \& L. Aase (red.). Kulturmøte $i$ tekstar. Litteraturdidaktiske perspektiv (s. 106-125). Oslo: Det Norske Samlaget.

Andersen, C. E. (2015). Mot en mindre profesjonalitet. «Rase», tidlig barndom og Deleuzeoguattariske blivelser. (Diss.) Stockholm: Stockholms Universitet.

Bakhtin, M. M. (1986/2006). Rum, tid og historie. Kronotopens former i europaisk litteratur. (Oversatt av H. Jepsen). Århus: Forlaget Klim.

Barad, K. (2007). Meeting the Universe Halfway. Quantum Physics and the Entaglement of Matter and Meaning. Durham \& London: Duke University Press.

Berliner, P. F. (1994). Thinking in fazz. The Infinite Art of Improvisation. Chicago: The University of Chicago Press.

Bresler, L. (2005). What musicianship can teach educational research. Music Education Research, 7(2), $169-183$.

Colebrook, C. (2002). Gilles Deleuze. New York: Routledge.

Coleman, R. \& Ringrose, J. (2013). Introduction: Deleuze and Research Methodologies. I R. Coleman \& J. Ringrose (red.), Deleuze and Research Methodologies (s. 1-23). Edinburgh: Edinburgh University Press Ltd.

Daykin, N. (2004). The role of music in arts-based qualitative inquiry. International fournal of Qualitative Meth$o d s, 3(2), 36-44$.

Deleuze, G. (1968/2014). Difference and Repetition. (Oversatt av P. Patton). New York: Bloomsbury Publishing Plc.

Deleuze, G. \& Guattari, F. (1975/1986). Kafka. Toward a Minor Literature. (Oversatt av T. Cochran). Minneapolis: University of Minnesota Press.

Deleuze, G. \& Guattari, F. (1991/1994). What is Philosophy? (Oversatt av H. Tomlinson \& G. Burchill). London: Verso.

Deleuze, G. \& Guattari, F. (1987/2013). A Thousand Plateaus. (Oversatt av B. Massumi). New York: Bloomsbury Publishing Plc.

Deleuze, G. \& Parnet, C. (1977/2015). Dialoger. (Oversatt av K. Mouritzen). København: Forlaget Basilisk.

Gadamer, H-G. (2003). Hva er sannhet? I H. Jordheim (red.), Forståelsens filosofi. Utvalgte hermeneutiske skrifter (s. 15-33). Oslo: Cappelens Forlag. 


\section{O. Harstad}

Gubrium, J.F. \& Holstein, J.A. (1997). The new language of qualitative methods. New York: Oxford University Press.

Harstad, O. (2017). Et forsøk på å skissere en norskfaglig begivenhetstenkning. Norsklcereren tidsskrift for språk, litteratur og didaktikk, 41(2), 21-27.

Harstad, O. (pågående ph.d.-avhandling). Mot en mindre litteraturlcerer. En fremskriving av problemet om litteraturlcererens bliven. (Diss.). Trondheim: NTNU.

Heidegger, M. (1935/2000). Kunstverkets opprinnelse. (Oversatt av E. Øverenget). Oslo: Pax Forlag.

Jackson, A. Y. \& Mazzei, L.A. (2012). Thinking with Theory in Qualitative Research.Viewing data across multiple perspektives. New York: Routledge.

Jenoure, T. (2002). Sweeping the Temple: a performance collage. I C. Bagley \& M.B Cancienne (red.), Dancing the Data (s. 73-89). New York: Peter Lang.

Jensen, A. (1965/2002). Epp. Oslo: Cappelen Damm.

Karlsen, G. (2006). Stilt overfor det som ennå ikke er. I K Steinsholt \& H. Sommero (red.), Improvisasjon. Kunsten å sette seg selv på spill (s. 239-261). Oslo: Damm og Søn.

Koro-Ljungberg, M. (2016). Reconceptualizing Qualitative Research. Methodoligies without Methodology. California: Sage Publications.

Kvarv, S. (2010). Vitenskapsteori - tradisjoner, posisjoner og diskusjoner. Oslo: Novus forlag.

Leavy, P. (2015). Method Meets Art. Arts-Based Research Practice. New York: The Guilford Press.

Macnaghten, P. \& Myers, G. (2004). Focus groups ph.d.-prosjektet. I C. Seale, Gobo, Gubrium \& Silverman. et.al. (red.), Qualitative research practice (s. 65-79). London: Sage Publications Ltd.

Nyrnes, A. (2002). Det didaktiske rommet. Didaktisk topologi i Ludvig Holbergs "Moralske Tanker». (Diss.). Bergen: Universitetet i Bergen.

Olsson, L. M. (2014). Rörelse och experimenterande $i$ små barns lärande: Deleuze och Guattari i förskolan. Lund: Studentlitteratur.

Pässila A., Owens, A \& Pulkki, M. (2016). Learning Jam: An evaluation of the use of arts based initiatives to generate polyphonic understanding in work based learning. Higher Education Skills and Work-Based Learning, 6(2), 178-192.

Peters, G. (2009). The Philosophy of Improvisation. Chicago: The University of Chicago Press.

Schatzki, T.R. (2010). The Timespace of Human Activity. On Performance, Society, and History as Indeterminate Teleological Events. Plymouth: Lexington Books.

Steinsholt, K. \& Ness, S. A (2016). Motstrøms. A pninger i retning av en levende pedagogikk. Bergen: Fagbokforlaget. Store norske leksikon (2016). Fam session. Hentet fra https://snl.no/jam_session (tilgang 28.10.2016) 